\section{Flowering and Fruit Set of Pumpkin Cultivars under Field Conditions}

\author{
Suzanne Cady Stapleton ${ }^{1}$ \\ Suwannee Valley Research and Education Center, University of Florida, \\ Live Oak, FL 32060-7434
}

H. Chris Wien ${ }^{2}$

Department of Fruit and Vegetable Science, Cornell University, Ithaca, NY 14853

\author{
Roger A. Morse ${ }^{3}$ \\ Department of Entomology, Cornell University, Ithaca, NY 14853
}

Additional index words. Cucurbita pepo, pistillate flower, fruit production, pollination

\begin{abstract}
Field experiments with six pumpkin cultivars (Cucurbita pepo L.) were conducted in Ithaca, N.Y., in 1992 and 1993 to characterize the patterns of flowering and fruit set. Plants of all cultivars produced the greatest number of female flowers and exhibited the highest rate of fruit set 35-45 days after transplanting, during the first 2 weeks of greatest flower production ("peak bloom"). During the 3 weeks of peak bloom, each plant produced an average of 3.4 pistillate flowers in 1992 and 5.4 in 1993, and fruit set was $50.9 \%$ in 1992 and $74.6 \%$ in 1993, yielding 1.7 and 4.0 fruit per plant, respectively. In 1994, flower production was further studied with the cultivar Wizard. Flowers were produced in a ratio of 33 staminate to 1 pistillate flower over the entire season. Climatic conditions appeared to be secondary to physiological factors in affecting flowering and fruit set during all three seasons. Characterization of fruit set patterns in pumpkin may aid producers in scheduling pollination services and predicting yields.
\end{abstract}

Sales returns up to $\$ 9880 /$ ha from pumpkins have made the crop important to farmers in New York (Riggs, 1991). Low pumpkin yields, thought to be a result of poor fruit set, have been repeatedly reported across the state by growers and extension agents since 1989. The causes of low yields in spite of abundant flowering have not been determined. Pumpkins are an entomophilous crop, typically pollinated by bees. Diseases and predatory mites reduced populations of wild and managed honey bees (Apis mellifera L.) in New York over 50\% between 1989 and 1993 (Morse, 1994), raising concerns about yields of bee-pollinated crops, including pumpkins. However, extreme temperatures or precipitation could also influence flowering and fruit set. Flowering and fruit development of related crops such as melons ( $\mathrm{Cucu}$ mis melo L.) and cucumbers (Cucumis sativus L.) have been extensively investigated (e.g.,

Received for publication 8 July 1999. Accepted for publication 3 Feb. 2000. Research conducted at Ithaca, N.Y. Paper no. 64 of the Dept. of Fruit and Vegetable Science, Cornell Univ., Ithaca, N.Y. Partial financial support for this study was provided by Federal Hatch Act funds (Project no. NYC-161425, U.S. Dept. of Agriculture). The cost of publishing this paper was defrayed in part by the payment of page charges. Under postal regulations, this paper therefore must be hereby marked advertisement solely to indicate this fact.

${ }^{1}$ Multi-County Extension Agent. E-mail address: suzanne@gnv.ifas.ufl.edu

${ }^{2}$ Professor.

${ }^{3}$ Professor Emeritus, deceased. sults have proven beneficial for hybrid seed production. The majority of domesticated cucurbits are monoecious and exhibit a succession of flower development, with a decreasing ratio of staminate to pistillate flowers as the plants mature (Nitsch et al., 1952; Robinson and Decker-Walters, 1997). Floral sex expression in the Cucurbitaceae is presumably controlled by endogenous hormones whose levels may vary in response to environmental conditions (Robinson and DeckerWalter, 1997). Little research has addressed fruit production of pumpkin. The objective of this study was to characterize patterns of flowering and fruit set of pumpkins under typical field conditions in New York.

\section{Materials and Methods}

Cultivar comparison. Six pumpkin cultivars were compared for flowering and fruit set patterns during two seasons of field experimentation in Ithaca, N.Y. Seeds were sown in "Cornell Mix A" peat-vermiculite medium (Boodley and Sheldrake, 1973) in Todd Planter Trays (Sun City, Fla.) of $80 \mathrm{~mL}$ individual cell volume on 26 May and 8 June 1992 and on 27 May and 11 June 1993. Seedlings were maintained in glasshouse culture with weekly fertilization for 3 weeks, then transplanted into Arkport fine sandy loam soil (coarse-loamy, mixed, mesic psammentic Hapludalf) outdoors in East Ithaca, N.Y., in a randomized complete-block design with two planting dates each year to
Nijs and Miotay, 1991; Rosa, 1924) and re- distribute labor requirements. Seedlings of two replicates were transplanted on 16 June of 1992 and 1993. Plants for two additional replicates were transplanted on 29 June 1992 and 30 June 1993. Seedlings were planted in single-row plots $1.8 \mathrm{~m}$ apart with $0.76 \mathrm{~m}$ between the six plants in each plot. A row of pumpkins surrounded the experiment on the field edges.

At the time of these trials, $\approx 80 \%$ of commercial pumpkin acreage in New York State was planted with 'Howden' for use as jack-o'-lanterns. Four potential alternatives to 'Howden' were included in the trials, while 'Baby Bear' was added to investigate the impact of a miniature-fruited cultivar on fruit set. The six cultivars compared were: 'Howden' and 'Wizard' (Harris Moran Seed Co., Modesto, Calif.); 'Autumn Gold', 'Ghost Rider', and 'Baby Bear' (Johnny's Selected Seed, Albion, Me.); and 'Happy Jack' (Petoseed Co., Saticoy, Calif.).

Field plots were fertilized with 101 $\mathrm{kg} \cdot \mathrm{ha}^{-1} \mathrm{~N}$ in the form of urea 3 weeks prior to first planting. Prior soil tests indicated adequate soil levels of $\mathrm{P}$ and $\mathrm{K}$. Plots were irrigated overhead as necessary. Vines were manually trained each week in an attempt to separate plants from different plots. Pests were controlled, as necessary, according to standard recommended practices (Cornell Cooperative Extension, 1992). Weekly air temperature, solar radiation, and precipitation data were obtained from the Northeast Regional Climate Center weather station located $3 \mathrm{~km}$ from the field.

All pistillate blossoms that attained anthesis during the 3 weeks of peak bloom were marked with a flag, color-coded by week. Fruit set of each flagged flower was noted $5 \mathrm{~d}$ after anthesis. Set was defined as development of fruit that maintained normal color and enlarged to at least fist-size $(\approx 8 \mathrm{~cm}$ in diameter). Fields were harvested by hand on 23 Sept. 1992 and 22 Sept. 1993. Fresh weight, uniformity, shape, color, and peduncle (handle) quality of fruit were recorded at harvest.

The number of pistillate flowers at anthesis was tabulated weekly and the percentage of fruit set by these flowers was calculated. The relative contribution to seasonal fruit production by each week of peak bloom was analyzed. The range of fruit set exceeded $40 \%$, suggesting arcsin transformation of data (Little, 1985). There were no significant differences in the results of analysis of variance (ANOVA) between original and transformed data. Therefore, for ease of interpretation, original data were used for analysis (Scheffe, 1959).

Analysis of variance was used to determine the significance of the differences observed and accounted for variability due to cultivar, planting date, week of anthesis, and interactions of these factors. Differences were detected with Fisher's protected least significant difference (LSD) test at $P \leq 0.05$ (Superanova Accessible General Linear Modeling, 1989).

Flower production. Four plots of 'Wizard' pumpkin plants were observed for 
Table 1. Number of pistillate flowers per plant open and set per week of peak bloom for six pumpkin cultivars at Ithaca, N.Y., in 1992 and 1993, and yield components in 1993 .

\begin{tabular}{|c|c|c|c|c|c|c|c|c|c|}
\hline \multirow[b]{3}{*}{ Cultivar } & \multicolumn{3}{|c|}{1992} & \multicolumn{6}{|c|}{1993} \\
\hline & \multicolumn{2}{|c|}{ No. pistillate flowers } & \multirow{2}{*}{$\begin{array}{c}\text { Fruit set } \\
(\%)\end{array}$} & \multicolumn{2}{|c|}{ No. pistillate flowers } & \multirow{2}{*}{$\begin{array}{c}\text { Fruit set } \\
(\%)\end{array}$} & \multirow{2}{*}{$\begin{array}{c}\text { Yield }^{z} \\
\left(\mathrm{~kg} \cdot \mathrm{ha}^{-1}\right)\end{array}$} & \multirow{2}{*}{$\begin{array}{l}\text { No. fruit } \\
\text { per ha }\end{array}$} & \multirow{2}{*}{$\begin{array}{c}\text { Fruit } \mathrm{wt}^{\mathrm{y}} \\
(\mathrm{kg})\end{array}$} \\
\hline & Open & Set & & Open & Set & & & & \\
\hline Autumn Gold & $1.32 \mathrm{~b}^{\mathrm{x}}$ & $0.64 \mathrm{~b}$ & $37.1 \mathrm{a}$ & $1.43 \mathrm{c}$ & $1.10 \mathrm{~b}$ & $77.4 \mathrm{~b}$ & 24,532 & $8,133 b^{x}$ & $3.1 \mathrm{c}$ \\
\hline Baby Bear & $1.85 \mathrm{c}$ & $1.17 \mathrm{c}$ & $49.1 \mathrm{ab}$ & $3.05 \mathrm{~d}$ & $1.96 \mathrm{c}$ & $61.6 \mathrm{a}$ & 8,666 & $15,866 \mathrm{a}$ & $0.5 \mathrm{~d}$ \\
\hline Ghost Rider & $0.90 \mathrm{ab}$ & $0.40 \mathrm{ab}$ & $42.1 \mathrm{a}$ & $1.13 \mathrm{abc}$ & $0.92 \mathrm{ab}$ & $78.4 \mathrm{~b}$ & 16,666 & $3,600 \mathrm{~b}$ & $4.8 \mathrm{ab}$ \\
\hline Happy Jack & $0.77 \mathrm{a}$ & $0.43 \mathrm{ab}$ & $69.4 \mathrm{c}$ & $0.97 \mathrm{ab}$ & $0.83 \mathrm{ab}$ & $86.2 \mathrm{~b}$ & 22,132 & $4,133 \mathrm{~b}$ & $5.5 \mathrm{ab}$ \\
\hline Howden & $0.53 \mathrm{a}$ & $0.33 \mathrm{a}$ & $59.4 \mathrm{bc}$ & $0.77 \mathrm{a}$ & $0.67 \mathrm{a}$ & $85.4 \mathrm{~b}$ & 23,732 & $4,000 \mathrm{~b}$ & $6.6 \mathrm{a}$ \\
\hline Wizard & $0.88 \mathrm{ab}$ & $0.46 \mathrm{ab}$ & $48.0 \mathrm{ab}$ & $1.27 \mathrm{bc}$ & $0.88 \mathrm{ab}$ & $58.8 \mathrm{a}$ & 23,066 & $5,200 \mathrm{~b}$ & $4.6 \mathrm{bc}$ \\
\hline
\end{tabular}

${ }^{2}$ Estimated from number of marketable fruit and mean fruit weight.

${ }^{y}$ Mean weight of individual fruit calculated from subsample of five fruit per plot.

${ }^{\times}$Mean separation within columns by Fisher's protected LSD, $P \leq 0.05$.

staminate and pistillate flowering patterns and fruit set data. The plants were sown on 25 May 1994 and transplanted on 15 June into single-row plots at the same spacing as above. The method of seedling production, transplanting, and field crop maintenance was the same as in 1992 and 1993.

All staminate and pistillate flowers were counted at anthesis during the growing season. Fruit set was determined as in prior years. Air temperature was recorded in the field and precipitation and solar radiation were recorded at the local Northeast Regional Climate Center.

\section{Results and Discussion}

In all 3 years, plants of all cultivars began to flower 25-30 d after transplanting (DAT). Anthesis of staminate flowers preceded the opening of the first pistillate flowers by $\approx 5 \mathrm{~d}$. Thereafter, both staminate and pistillate flowers were in bloom. This pattern of floral sex expression is common in the Cucurbitaceae (Robinson and Decker-Walters, 1997). The greatest number of pistillate flowers reached anthesis $\approx 30-50$ DAT; this period is hereafter referred to as "peak bloom."

Cultivar comparison. The six cultivars studied in 1992 and 1993 consistently produced significantly different numbers of mature pistillate flowers, with the miniature pumpkin, 'Baby Bear', producing the most. Among the jack-o'-lantern types, 'Autumn Gold' produced the most female flowers per plant and 'Howden' the least (Table 1). For all cultivars, the number of pistillate flowers reaching anthesis differed significantly during each week of the peak flowering period. In both years, the greatest number of female flowers per plant $(1.6 \pm 0.2$ in 1992 and $1.8 \pm$ 0.3 in 1993) were produced in the second week of peak bloom (Fig. 1).

Not all pistillate flowers set fruit. The mean number of pistillate flowers setting fruit differed among the six cultivars, following the same pattern as the total number of pistillate blossoms at anthesis. In both years, 'Baby Bear' set significantly more fruit than did all of the large-fruited pumpkins (Table 1), and 'Howden' set significantly fewer fruit than did 'Autumn Gold'. Excluding the miniature pumpkin, the mean number of fruit set per plant per week during peak

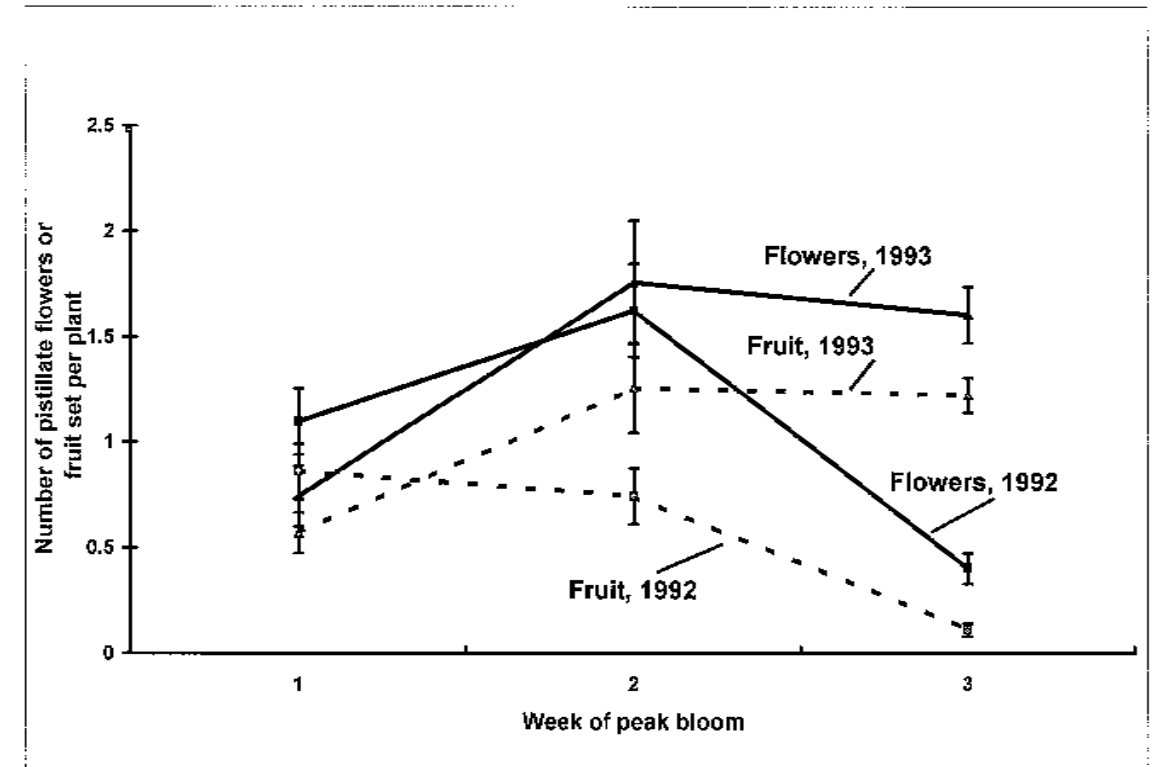

Fig. 1. Mean number of pistillate flowers at anthesis and fruit set per plant for six pumpkin cultivars during 3 weeks of peak bloom in 1992 and 1993.

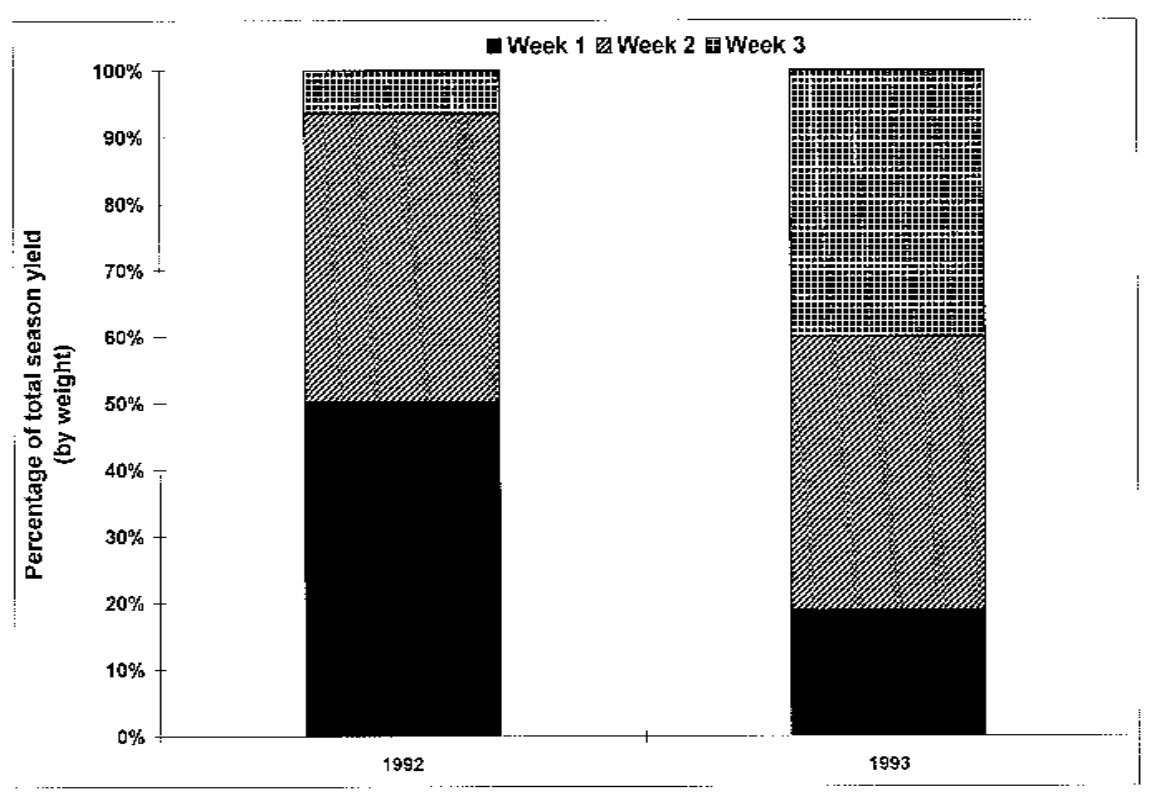

Fig. 2. Percentage of total season fruit set in pumpkin during each week of peak bloom in 1992 and 1993. 
bloom was $0.45 \pm 0.05$ in 1992 and $0.88 \pm$ 0.07 in 1993 . Fruit set was lowest in the final week of peak bloom in both years $(28 \%$ in 1992; 61\% in 1993) (Fig. 1).

In both years of this study, $>60 \%$ of the crop was produced from flowers set during the first 2 weeks of flowering (Fig. 2), and $>50 \%$ in 1992 from flowers set during the first week of peak bloom in both plantings (Fig. 2), 39-45 DAT in the first planting and 35-41 DAT in the second planting. In 1993, $>40 \%$ of the total fruit was produced from fruit set in the second week, 38-44 and 35-41 DAT in the first and second plantings, respectively. The importance of fruit set from early season flowers suggests that pumpkins exhibit "first-fruit dominance," the temporary inhibition of flowering and fruit maturation by actively growing fruit (Stephenson et al., 1988). Repeated fruit removal in two cultivars of squash (Cucurbita pepo L.) tripled pistillate flower production (El-Keblawy and Lovett-Doust, 1996). Recent research with Cucurbita texana (Scheele) A. Gray, a progenitor of $C$. pepo, indicated that developing fruits maintain temporary dominance by suppressing pistillate flower production via ethylene regulation at terminal apices where floral buds differentiate (Krupnick et al., 1999).

In $1992, \approx 3.4$ pistillate flowers were produced per plant during peak bloom. Fruit set among all six cultivars averaged $50.9 \%$, resulting in 1.7 fruit per plant. In 1993, an average of 5.4 pistillate flowers developed per plant during peak bloom, with $74.6 \%$ successful fruit set, resulting in 4.0 fruit per plant. Throughout flowering and fruit set, temperatures were 1.6 to $2.5^{\circ} \mathrm{C}$ cooler in 1992 than the normal $20.3{ }^{\circ} \mathrm{C}$ in July and $19.4^{\circ} \mathrm{C}$ in August. Rainfall in July and Aug. 1992 was $26.4 \mathrm{~mm}$ above the normal 87.5 $\mathrm{mm}$ per month. Temperature and rainfall in 1993 were near normal, and solar radiation was greater than normal. Wetter, cooler, and cloudier conditions in 1992 may explain the reduction in fruit set, possibly as a result of less successful pollination and greater flower abortion because of a reduced supply of photosynthate.

Most of the flowers that set fruit in these studies produced mature pumpkins, although yields in 1992 were reduced by several late season diseases. In 1993, experimental plots yielded $22,026 \mathrm{~kg} \cdot \mathrm{ha}^{-1}$ of fruit (excluding the cultivar with miniature fruit) (Table 1), which is comparable with average commercial yields for New York [22,428-67,283 $\mathrm{kg} \cdot \mathrm{ha}^{-1}$ (D.I.M. Riggs, pers. comm.; E. Rutkowski, pers. comm.)].

Flower production. In 1994, the ratio of staminate : pistillate blossoms over the entire season was 33:1. 'Wizard' pumpkins produced $90.2 \pm 1.8$ staminate and $2.75 \pm 0.1$ pistillate flowers per plant, of which $1.7 \pm 0.2$ set fruit. The number of staminate flowers reaching anthesis each week increased throughout the season (Fig. 3A). This in-

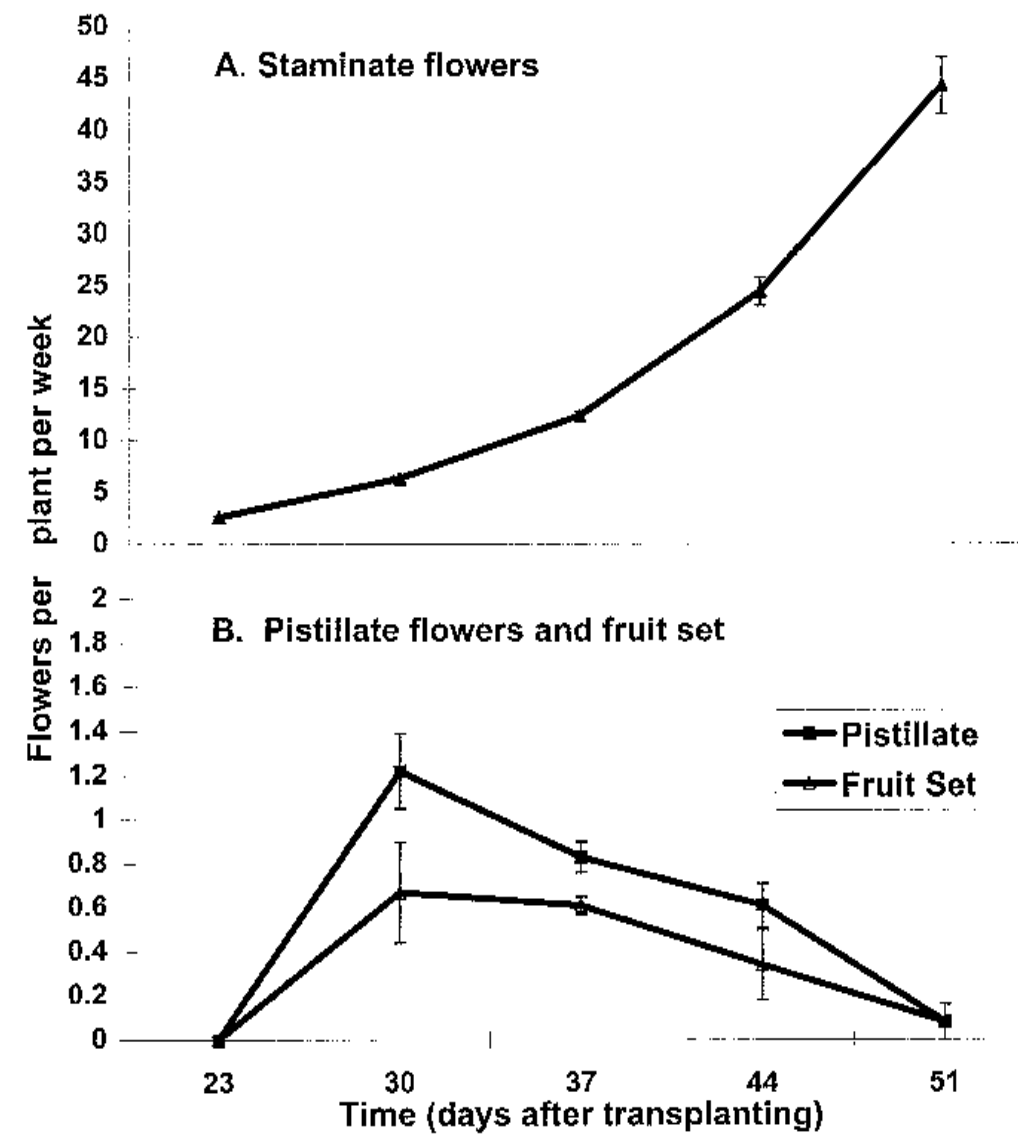

Fig. 3. Number of (A) staminate and (B) pistillate flowers and fruits set per plant in 'Wizard' pumpkin in 1994, 23-51 d after transplanting.

crease may result from coevolution with wild squash and gourd bees that rely solely on cucurbits for pollen (Hurd et al., 1971). Pistillate flowers were much more limited in number and time of appearance (Fig. 3B). The ratio of staminate to pistillate flowers and the earlier anthesis of staminate blooms are similar to reports for other cucurbit crops. In eight cucurbit species, including C. pepo, Whitaker (1931) reported staminate flowers outnumbered pistillate flowers at all times and often reached anthesis 1 week prior to the first pistillate blossom. NeSmith et al. (1994) found that floral sex ratios varied among summer squash [C. pepo var. melopepo (L.) Alef.] cultivars and were affected by weather conditions. In the flower production study, the greatest number of pistillate flowers per plant at anthesis in 1994 was $1.2 \pm 0.2$ and occurred 27-33 DAT. Fruit production per plant in 'Wizard' paralleled pistillate flower production (Fig. 3B).

Results of field studies in 1992, 1993, and 1994 indicate that pumpkins have a consistent flowering pattern in Ithaca, N.Y., in spite of minor differences in environmental conditions. The cooler and wetter conditions may explain the reduced fruit set in 1992. However, environmental conditions were not extreme in any year.

Producers and researchers may use the results of these studies to better schedule pollination services and more accurately estimate expected pumpkin yields. Beehives should be introduced at the start of peak bloom for maximum pollination activity. Anthesis of flowers in New York pumpkin fields could serve as indicators for the need to introduce beehives within $10-14 \mathrm{~d}$ of the opening of the first staminate flower and within 1 week of that of the first pistillate flower. The greatest contribution to seasonal yields in these trials resulted from fruit set from flowers at anthesis $\approx 35-45 \mathrm{~d}$ after transplanting. By scouting fields to estimate average fruit set after this period, pumpkin producers may be able to make early predictions of actual field yields.

\section{Literature Cited}

Boodley, J.W. and R. Sheldrake Jr. 1973. Cornell peat-lite mixes for commercial plant growing. Cornell Univ. Inform. Bul. 43. Ithaca, N.Y.

Cornell Cooperative Extension. 1992. Pest management recommendations for commercial vegetable and potato production. Ithaca, N.Y.

den Nijs, A.P.M. and P. Miotay. 1991. Fruit and seed set in the cucumber (Cucumis sativus L.) in relation to pollen tube growth, sex type, and parthenocarpy. Gartenbauwissenschaft 56:4649.

El-Keblawy, A. and J. Lovett-Doust. 1996. Resource re-allocation following fruit removal in cucurbits: Patterns in two varieties of squash. New Phytol. 133:583-593.

Hurd, P.D., Jr., E.G. Linsley, and T.W. Whitaker. 1971. Squash and gourd bees (Peponapis, Xenoglossa) and the origin of the cultivated Cucurbita. Evolution 25:218-234.

Krupnick, G.A., K.M. Brown, and A.G. Stephenson. 1999. The influence of fruit on the regulation of internal ethylene concentrations and sex expres- 
sion in Cucurbita texana. Intl. J. Plant Sci. 160:321-330.

Little, T.M. 1985. Analysis of percentage and rating scale data. HortScience 20:642-644.

Morse, R.A. 1994. Prepare for bee shortages. Amer. Agriculturalist 191(2):34A.

NeSmith, D.S., G. Hoogenboom, and D.W. Groff. 1994. Staminate and pistillate flower production of summer squash in response to planting date. HortScience 29:256-257.

Nitsch, J.P., E.B. Kurtz, Jr., J.L. Liverman and F.W.
Went. 1952. The development of sex expression in cucurbit flowers. Amer. J. Bot. 39:3243.

Riggs, D.I. M. 1991. The fruit set problem of 1991. Capital Veg. News. September 1:4. Cornell Coop. Ext.. Albany, N.Y..

Robinson, R.W. and D.S. Decker-Walters. 1997. Cucurbits. CAB Intl., New York.

Rosa, J.T. 1924. Fruiting habit and pollination of cantaloupe. Proc. Amer. Soc. Hort. Sci. 21:5157.
Scheffe, H. 1959. The analysis of variance. Wiley, New York.

Stephenson, A.G., B. Devlin, and J.B. Horton. 1988.

The effects of seed number and prior fruit dominance on the pattern of fruit production in Cucurbita pepo (zucchini squash). Ann. Bot. 62:653-661.

Superanova Accessible General Linear Modeling. 1989. Abacus Concepts. Berkeley, Calif.

Whitaker, T.W. 1931. Sex ratio and sex expression in the cultivated cucurbits. Amer. J. Bot. 18:359-366. 